Article

\title{
"Trees Are Our Relatives": Local Perceptions on Forestry Resources and Implications for Climate Change Mitigation
}

\author{
Nelson Chanza *(i) and Walter Musakwa (D) \\ Department of Urban and Regional Planning, University of Johannesburg, Johannesburg 2028, South Africa; \\ wmusakwa@uj.ac.za \\ * Correspondence: nchanza@gmail.com; Tel.: +27-68-431-6006
}

Citation: Chanza, N.; Musakwa, W.

"Trees Are Our Relatives": Local

Perceptions on Forestry Resources and Implications for Climate Change Mitigation. Sustainability 2021, 13, 5885. https://doi.org/10.3390/ su13115885

Academic Editors: Abiy S. Kebede and Shona K. Paterson

Received: 1 April 2021

Accepted: 14 May 2021

Published: 24 May 2021

Publisher's Note: MDPI stays neutral with regard to jurisdictional claims in published maps and institutional affiliations.

Copyright: (c) 2021 by the authors. Licensee MDPI, Basel, Switzerland. This article is an open access article distributed under the terms and conditions of the Creative Commons Attribution (CC BY) license (https:/ / creativecommons.org/licenses/by/ $4.0 /)$.

\begin{abstract}
The link between nature and society is vital for climate change mitigation and sustainable natural recourse management. Based on a case study of the indigenous people of Mbire in Zimbabwe, we argue that perceptions of indigenous people about forestry resources provide useful pointers toward framing climate mitigation interventions. This interest was necessitated by the growing call to address the suppression of forest-rich indigenous communities in climate change science. Accordingly, the aim of the study was to understand how indigenous people can contribute to the abatement of climate change. The study engaged 32 purposively selected elderly participants in focus group discussions; these participants had long histories of staying in the villages studied and were figures whom the locals regarded as "experts" in giving credible inferences about their environment. The participants corroboratively perceived forests and trees as their own "relatives", who should not be harmed because of the support they continue to generously give to the people. Their construct of climate change relates to the gradual but continuing trivialization of cultural beliefs and abandonment of traditional practices, which they believe offend the spirits who have powers to influence the climate system. Although their attribution view on climate change is in contrast with that of mainstream climate scientists, we argue that their profound acknowledgement of climatic change, coupled with their scientific understanding of the intrinsic relationship between people's wellbeing and the environment, are key entry points to design sustainable climate mitigation programs at community scales. The sustainability of such programs should not ignore local belief systems and strategies that communities use in preserving their forests.
\end{abstract}

Keywords: climate change; forests; indigenous knowledge; sustainability; Zimbabwe

\section{Introduction}

The surge in interest in examining indigenous knowledge (IK) in climate science can be attributed to the convergence of the multiple evidence base approach [1-3] with the threat of climate change itself [4,5]. Many researchers treating IK and climate change bemoan the lack of meaningful participation of indigenous people in framing mitigation practice and policy, despite their religious adherence to conservation practices that have helped in maintaining forest ecosystems across the world [6-8]. Accordingly, the agenda to incorporate the previously ignored contributions of indigenous people in climate science is understood to be decolonial [9] and continues to gather momentum. Notwithstanding this burgeoning interest, there are still operational deficiencies in terms of how the knowledge held by indigenous people and local communities can inform climate change mitigation. This limitation can be explained largely by the narrower spatial scale at which IK has been applied [10-12]. Apparently, existing studies on indigenous people and climate change have tended to adopt an adaptation bias, with limited examination of how local communities use their extensive historical knowledge about their environment to participate in mitigation interventions. This could be because mitigation has largely been understood as a global concept without clearly defined benefits to indigenous populations. 
In climate change science, mitigation is defined as a human intervention both to suppress emissions and enhance greenhouse gas (GHG) sinks [4]. This implies that carbonsensitive land-use activities of indigenous people and strategies to properly manage forests can help in mitigating climate change. However, such practices have not been adequately documented and tend to be context-specific owing to the unique nature of IK practices. There is also a tendency to marginalize the potential contribution of mitigation benefits coming from the activities of indigenous people because of scale limitations. This study therefore argues that, despite scale constraints, there are mitigation contributions from indigenous people's practices of conserving forests that should be brought to the attention of climate change researchers, practitioners and policy makers. Furthermore the cumulative effect of indigenous people's efforts on climate change mitigation will likely have an impact on climate change mitigation globally.

Conscious of the existing heterogeneous terminologies, the study adopts the term "indigenous knowledge" to refer to environmental knowledge held by indigenous local populations and the unique traditional contexts in which this knowledge form is understood, developed and applied $[13,14]$. Through the use of their IK, acquired from many years of observing and experiencing environmental phenomena, local communities in various parts of the world have developed unique knowledge that they use to manage the environment and to gain a livelihood from it. Such knowledge systems are in the form of religious, traditional and cultural beliefs, customs and practices [1,13-15]. The aim of this study was to understand the potential mitigation contribution that indigenous and local communities can make towards the global imperative to cut GHG emissions and enhance carbon sinks. The study also responds to the United Nations Sustainable Development Goals (SDGs). The SDGs are a global plan of action designed to guide a pathway towards a sustainable future for all countries by 2030 . The goals specify that ending poverty and other development challenges must be addressed concurrently with strategies that improve health and education, reduce inequality and promote economic growth, while tackling climate change and preserving forests, ecosystems and water resources. Specifically, SDG 13 calls for "Taking urgent action to combat climate change and its impacts" [16]. By drawing from a typical indigenous setting in Mbire, Zimbabwe, where local understanding about landscape change appears to be not much tainted by scientific thoughts, the study examines the potential contribution of local knowledge and practices regarding forest management towards GHG abatement. To do this, the study first contextualizes IK in rural Zimbabwe, showing how this knowledge has shaped the state of the environment in the selected study area. It also describes the indigenous-based participatory methodology used to gather and analyze data. The results are discussed within the visibilist paradigm, which, according to Reyes-Garcia et al. [17], is based on the notion that observations of environmental phenomena are also visible to non-scientists. We conclude by highlighting possible nuances for escalating the mitigation agenda involving indigenous communities.

\section{Related Scholarship}

There has been remarkable attention paid to examining the role of IK in climate science [8,14,17-19]. Orlove et al. [18] and Chanza and de Wit [9] use the term "indigenous climate knowledge" to link these topics, referring to it as the knowledge, skills, technologies and practices of an indigenous community consisting of local experts who have long-term experience with change and variability in their local climate system. The community is capable of sharing and utilizing this knowledge to meet their livelihood and survival needs. There is evidence that indigenous climate knowledge is useful across the climate change spectrum, from climate impact assessment $[1-3,11,13,20-24]$ to adaptation [25-30] and mitigation [9,31]. Scholars advocating for climate change-IK integration argue that the understanding of climate change can be enhanced by harnessing the knowledge of indigenous people who have been religiously observing changes occurring in their environment. In addition, indigenous knowledge systems, encompassing local 
customs, myths and beliefs, are believed to enhance climate change responses in the form of mitigation and adaptation strategies that suit specific localities [28,31].

Despite significant strides in demonstrating how indigenous societies can use their knowledge to comprehend local climate change impacts and to advance climatic responses, there has not been much attention given to the relationship between IK and climate change mitigation. Earlier attempts by Nyong et al. [31] indicated that employing mitigation strategies through indigenous natural resource conservation serves dual objectives by reducing GHG emissions from anthropogenic sources and enhancing carbon assimilation. However, the mechanisms by which the activities and practices of indigenous people can be said to be climate-sensitive are not adequately understood and they tend to be localized. As such, studies on climate change and IK focus more on adaptation than mitigation. This adaptation preference also follows the ongoing debate about the rights and justice issues associated with indigenous populations who are known to be innocent victims of climate change $[29,31,32]$. In addition, the mitigation-adaptation "marriage" is believed to continuously subjugate indigenous people, hence resulting in separate treatment by most scholars, who prefer to focus on adaptation. For example, Tol [33] argues that mitigation takes away resources from adaptation while Adger et al. [34] and Chishakwe et al. [35] state that adaptation benefits are mostly experienced at local scales but that mitigation benefits tend to be, essentially, global. However, from the viewpoints of Nyong et al. [31] and Wilbanks and Sathaye [36], the capacity of any community to adapt is based on GHG stabilization through mitigation. This means that adaptation will be a failure if mitigation fails to handle the costs of extreme climatic events. This study intends to address this bias by examining the strategies and practices that indigenous people use to conserve forests and the potential for such indigenous practices towards making climate mitigation sustainable.

\section{The Study Area}

Mbire District lies between $30.60^{\circ}$ and $31.20^{\circ}$ east and $15.60^{\circ}$ and $16.40^{\circ}$ south, on the northern side of Zimbabwe bordering Zambia to the northwest and Mozambique to the north (Figure 1). The area covered by the district is about $4700 \mathrm{~km}^{2}$. It exhibits a semi-arid climate where mean annual rainfall is below $650 \mathrm{~mm}$, while the mean maximum temperature is between 28 and $30{ }^{\circ} \mathrm{C}[37,38]$. Drought, dry spells, violent storms, seasonal flash and riverine floods are common climatic hazards and have increased in frequency in the area since 2002. The major rivers that drain the area are the Hunyani, Angwa, Dande, Mwanzamutanda, Musengezi and Kadzi. These rivers flow into the Zambezi River in Mozambique, which eventually empties into the Indian Ocean. Seasonal pans and ponds are also a common hydrological feature during the rainfall season when water accumulates in shallow depressions of the generally flat topography typical of the Zambezi River basin $[39,40]$.

The area is characterized by dry savanna vegetation, which is dominated by mopane and acacia forests and woodlands. Baudron et al. [41] reported high vegetation species diversity in the area. The vegetation consists of alluvial woodland, shrubland and riparian deciduous thickets. The woodland flora is dominated by mopane-terminalia (Colophospermum mopane and Terminalia stulhmani) and mopane-combretum (Colophospermum mopane and Combretum apiculatum), with dense riverine thickets of mixed species along the major rivers. Pure stands of mopane woodlands are prominent on poorly drained soils. The soil varies with place but calcic solonetz sodic soils tend to be dominant, with alluvial deposits found on the floodplains. The vegetation supports both wildlife and livestock [42].

The mopane woodlands are an important ecosystem providing communities with ecosystems services. They are a source of timber, fuelwood and construction materials for gardens, livestock pens and traditional huts [40]. The core livelihood activities in the area are dryland agriculture and livestock rearing. Flood recession farming of crops and vegetables is a common practice intended to utilize moisture and fertile soils brought by recurrent floods [37]. Goats and cattle are the major livestock kept and are a major source of livelihood. The Zambezian and mopane woodland is an important area for mammalian diversity, which consists of megafauna such as elephants, giraffes, buffalos, 
hippos, lions and zebras. The rich biodiversity has supported the establishment of safaris, namely Chewore, Doma and Dande, in the area. However, human-wildlife conflict is rife. Large elephant populations and lion attacks have been blamed for loss of human life and injuries, livestock deaths, damage to crops and destruction of property and infrastructure in the area. Crop raids are also undertaken by wild pigs, baboons and monkeys [43].

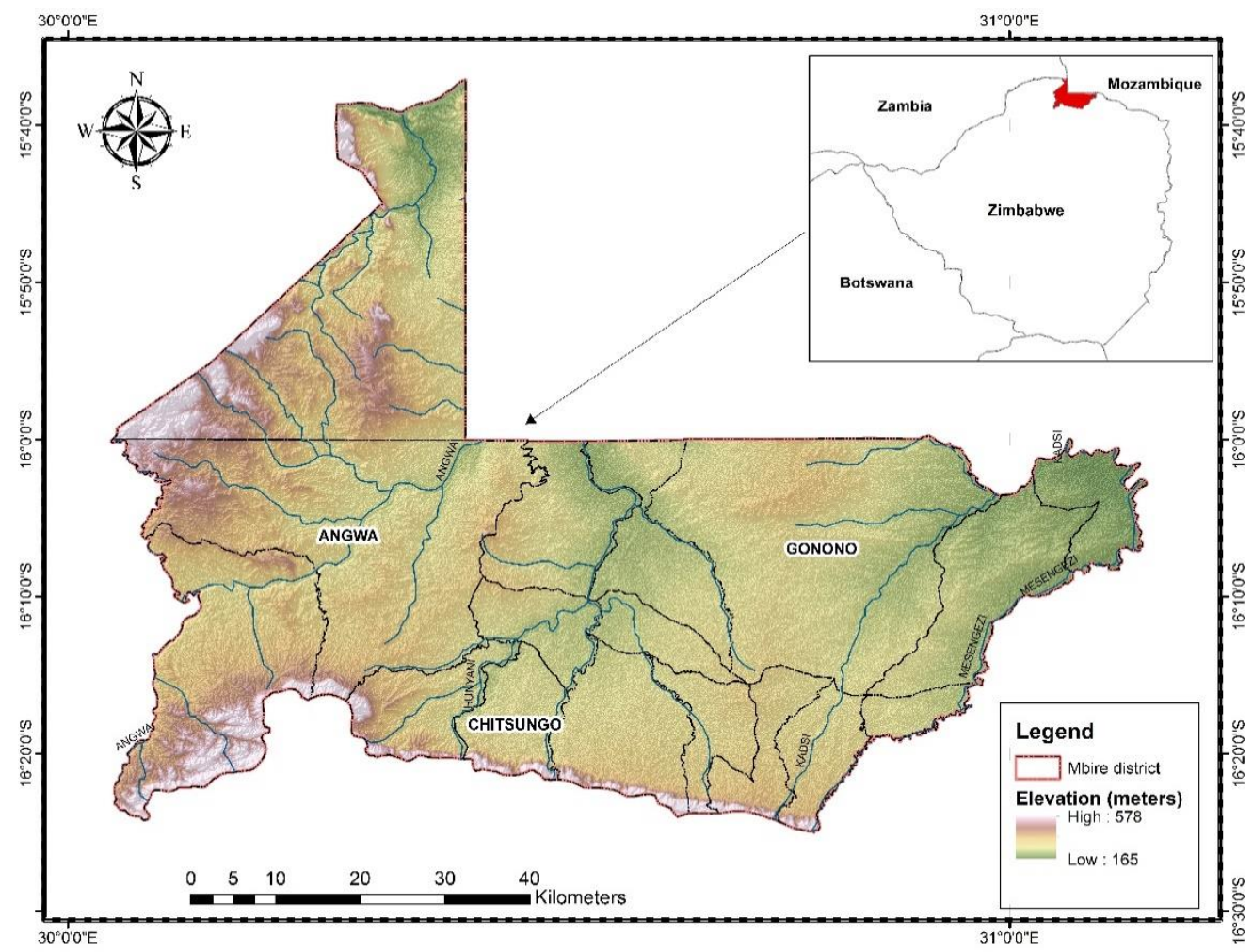

Figure 1. Location of Mbire District, Zimbabwe.

In addition, the rich wildlife has supported the establishment of conservation schemes, namely the Communal Area Management Program for Indigenous Resources (CAMPFIRE) and the United Nations-based program for Reducing Emissions from Deforestation and Forest Degradation (REDD+). CAMPFIRE evolved around the concept of managing wildlife and habitats in communal lands for local benefits. This was after realizing that, for people to tolerate the presence of wildlife and the threats to life and property, they had to substantially benefit and have a stake in natural resources management. The program was introduced by the Zimbabwe Parks and Wildlife Management Authority (ZPWMA) in 1989 and is implemented by rural district councils (RDCs) [39,43]. The REDD+ project seeks to prevent forest degradation over approximately 750,000 hectares of forest and also covers the other rural districts Binga, Nyaminyani and Hurungwe [44].

Mbire RDC is the legal authority responsible for the administrative affairs of the district as provided by the Rural District Councils Act of 1988. However, there is a de facto customary leadership system consisting of chiefs (madzishe), headmen (masadunhu) and village heads (masabhuku). These figures are involved in the day-to-day affairs of the rural communities and are the custodians of IK. Their operations are also governed by the Traditional Leaders Act of 1998. The traditional leaders are responsible for enforcing local customs and cultural values-including ensuring lawful land allocation and land uses-restrictions on natural resources exploitation and regulating human settlements. Despite this role, the law in Zimbabwe does not give power to the traditional leaders to manage wildlife but stipulates that wildlife is managed by the ZPWMA, while forestry resources are controlled by the Forestry Commission [9]. Figure 2 shows some of the landscape features of the study area. 

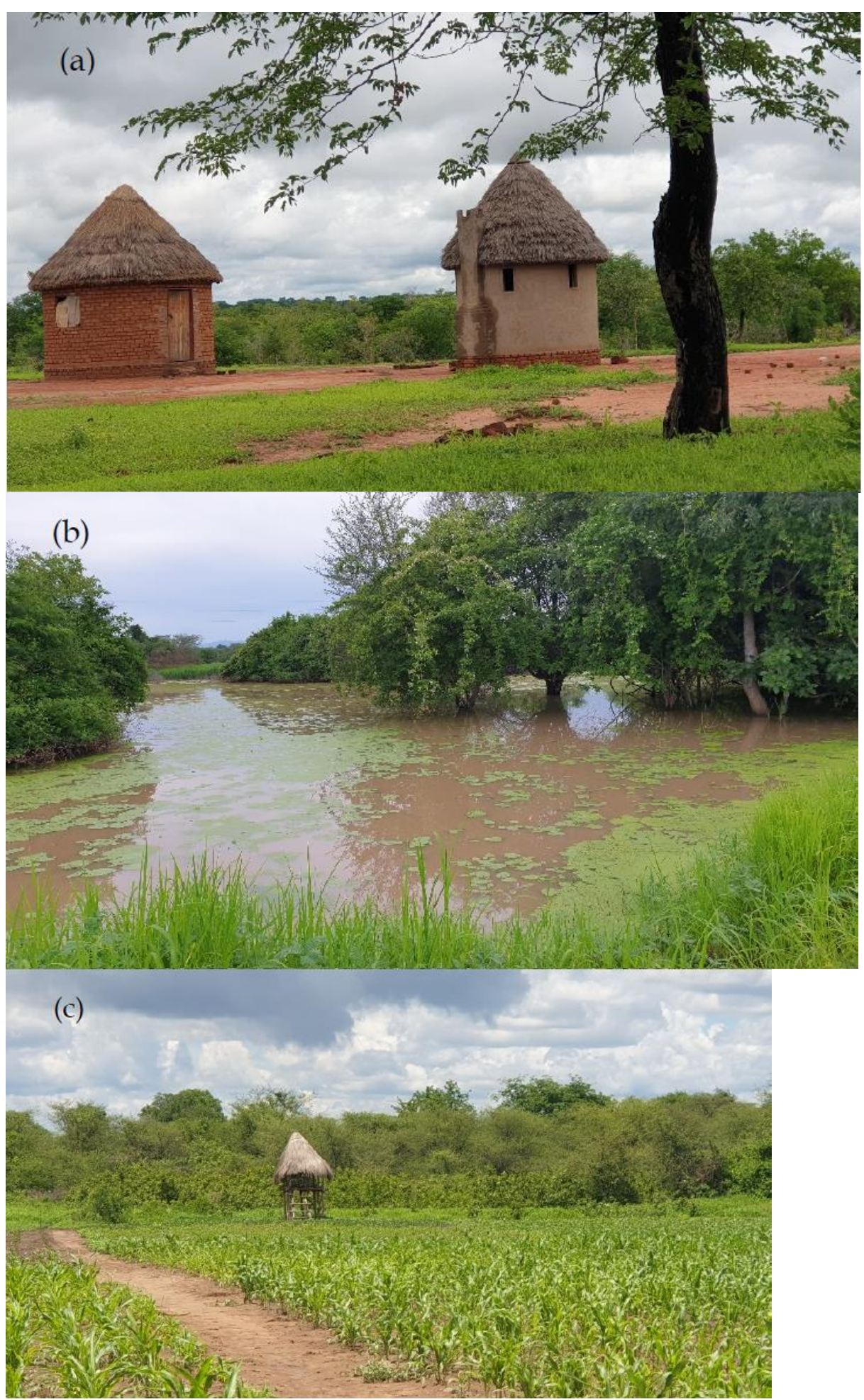

Figure 2. Landscape features in Mbire. (a) Homestead surrounded by woodlands. (b) Extensive water-filled pan. (c) Crop field surrounded by woodlands.

\section{Research Methods}

This qualitative study focused on three forest-rich indigenous villages, Angwa, Chitsungo and Gonono, in Mbire where the locals' perceptions about the environment were thought to be not much diluted by the scientific construct of forestry conservation. The study purposively selected 32 elderly villagers who participated in focus group discussions (FGDs). A total of 3 FGDs, one in each village, were conducted. Each FGD 
consisted of 9 to 12 male and female participants of ages 58 to 73 years. Interest was sought from participants who had lived in the area for long periods of time and could give rich accounts about their interaction with the local environment. These participants were selected through chain referrals after engaging the village head, who would indicate the most appropriate persons with sound knowledge about the local landscape from their long periods of inhabitation in the area. The participants were assembled at neutral venues where village meetings are usually held. Each FGD session lasted for about $150 \mathrm{~min}$. Guided field tours to observe certain tree species and forest sites were made at the end of each FGD. Field data collection with the participants was conducted between 9 December 2020 and 18 January 2021.

The FGD question guide was administered in the Shona language using the local Korekore dialect with the help of local research assistants from the villages. The discussion topics covered the participants' perceptions about trees and forests, changes in their landscapes and indigenous forest conservation practices, including the challenges they face in conserving the forests. The detailed questions that guided the discussions are included as Supplementary Material. Data analysis was conducted ex ante. The analysis process began during the FGD sessions in order to confirm the accuracy of responses recorded and to deduce meanings of local beliefs and expressions about environmental phenomena. The responses were read to the participants at the end of discussion sessions to check their accuracy before they were translated into English. By espousing this method, the analysis was guided by the multiple evidence paradigm, according to which the study assumed that the views of the villagers about local forests and conservation practices could be used to enhance knowledge of climate change mitigation [17]. The themes emerging from discussion topics formed the bases of the data analysis. Notwithstanding the need to portray the deeper meanings that the locals ascribed to the environment, data analysis was reflexively done to balance the views of the knowledge generators and the scientific audience [45]. Ethical clearance was sought from the Ethics and Plagiarism Committee of the University of Johannesburg under Ethical Clearance Number UJ_FEBE_FEPC_00046. The ethical guidelines covered debriefing, voluntary participation, informed consent, beneficence, confidentiality and anonymity and the right to withdraw from participation.

\section{Results and Discussion}

\subsection{Local Perceptions on Forestry Resources}

The participants' perceptions of forests were diverse, existing around thoughts and deeper feelings about spirituality and human-nature relations, livelihoods and wellbeing, and defense and protection (Figure 3).

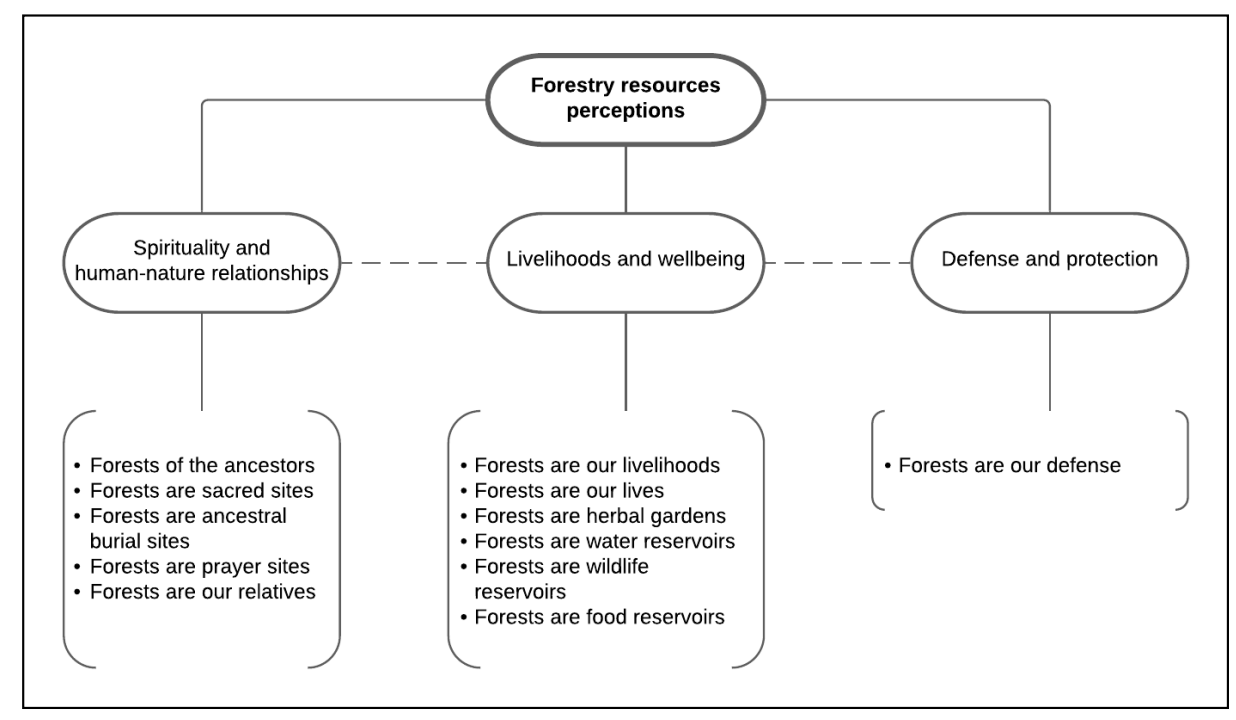

Figure 3. Local perceptions about forests in Mbire. 


\subsubsection{Spirituality and Human-Nature Relations}

A strong feeling about spirituality and human-nature connectedness exists in the villages studied. Participants perceive forests as areas where their ancestors dwell. Related to this view is the belief that the forests belong to the ancestors. As such, they have a collective obligation to protect the forests as per the requirements of the ancestors. "We worship our ancestors in the forests", proudly stated one elderly male participant in an FGD held in Chitsungo village, suggesting a profound spiritual attachment to the forests. They regard forests as sacred sites that they use to communicate with the vadzimu (ancestors) through masvikiro (spirit mediums). In addition, the forests are used as burial sites for the elders, whom they believe manifest as ancestors in certain trees and wild animals, particularly snakes and lions. As such, the forest is understood as a sacred environment which they also believe keeps the mhondoro (spirit lions). In the Shona traditional belief system, the mhondoro is a highly venerated spirit that manifests in lions. As such, lions are not regarded as ordinary animals but as spiritual lions. Some special types of snakes found in the forests, such as the python, are also not ordinary, but spiritual. If these animals are found coming to people's homes then it would be a sign that the forests have been disturbed or that people have misbehaved, causing the spirits to be upset. In one of the group discussions, participants expressed that

The ancestors dwell in the forests where they get some cover. So, what we see is not just forest cover, it is a cover of the spirits. The mhondoro [spirits] that protect us do not exist on bare land. They are found in dense cool forests where they are cooled from the scorching heat of the Dande valley. If these forests are destroyed, then the spirits will be angry. The lions will come to haunt us. They will come and eat our goats and cattle.

(FGD, Gonono)

A strong human-nature bond exists in the understanding of the villagers. To the participants, the tree or forest does not exist in isolation from the people. Participants in Angwa stated that "Miti ihama yemunhu" ("Trees are our relatives"), while those in Chitsungo added that "Miti nesu tirivamwechete" ("Trees are part of us"). These statements suggest that trees are viewed as living beings that influence the existence of their human counterparts. In other words, humans and trees are treated as one. This understanding obligates the villages to take care of their "relatives", who are part of their survival. Byers [42] also revealed this deep cultural understanding as critical in maintaining forest landscapes in many indigenous communities in Zimbabwe.

\subsubsection{Livelihoods and Wellbeing}

The connection between forests and the villagers' wellbeing was quite evident. The expression "Masango ndiyo ndaramo yedu" ("Forests are our livelihoods") suggests that the villagers' survival is largely dependent on the forestry resources. For example, they obtain food, water, honey, clean air and traditional medicines from the forests. In particular, the availability of different types of edible wild fruits at different times of the year is understood to be a blessing from the ancestors as captured in the following comment:

The ancestors generously provide us with various wild fruits during most times of the year. We have masau [Ziziphus mauritiana], matamba [Strychnos spinose], mauyu [Adansonia digitata], hacha [Parinari curatellifolia], chenje [Dyspros mespiliformis], siga [Tamarindus indicus] fruits, including ground tubers [manyanya-Dioscorea steriscus and mafebe] ripening differently between April and August, while tsvanzva [Ximenia caffra] and tuguru are found in December and January. Most of these fruits make us healthy and strong. Surely, something must be responsible for instructing these forest trees to bear fruits which mature at different times of the year.

(FGD, Chitsungo)

The dynamic pattern of the pestiferous nature of herbivorous wild animals, like elephants, baboons and monkeys, is used as an indicator of fruit abundance. The villagers 
stressed that they are obliged to share the fruits with the animals by restricting themselves to the forests around their homesteads. They regard it as a taboo to deplete the fruits that should be available to wild animals. Harvesting of fruits from sacred places is also forbidden, otherwise "the animals [such as baboons] would come and eat [their] crops and chickens". Traditional herbs and medicines are also obtained from the forests. The participants perceive a forest as an "herbal garden", or a "pharmacy" of medicines that they can freely get both to prevent and cure such common diseases as malaria and fever, as well as wounds and other ailments. The forest also provides medicines that they use to treat their livestock. The villagers believe that if the ancestors get upset, these resources will not be available. In the participants' understanding, it is through the availability of forests that "the ancestors nourish [them] with clean air for breathing", stressing that they "die if the forests are not there". To them, livelihoods and wellbeing are related to the generosity of the ancestors, whom they believe should not be angered by practices that affect the sustainability of the forests.

\subsubsection{Defense and Protection}

Related to the spiritual connections, the forests are believed to offer protection against perceived climatic and weather hazards, such as drought, floods and lightning and thunderstorms, including protection from problem animals. They understand that forests retard the progression or strength of violent storms and floods. For example, participants in Gonono emphasized that "Masango anotimudza hasha dzemhepo", meaning that forests prevent the devastation associated with violent storms. During drought years, or when food becomes scarce, people meet their food needs with resources from the forests. With reference to problem animals like elephants, crocodiles and lions, they believe that asking the favor of the ancestors is the only way to ensure their co-existence with wildlife. Naturally, wild animals are expected to stay in the forests without harming people. This suggests that the forests keep the animals from causing problems with people. However, if the forests are disturbed, "the protection vanishes and [they] get exposed to wildlife attacks". The increase in cases of human-wildlife conflict, which Jani et al. [43] attribute to increases in wildlife populations in the area, could also be related to forest disturbances associated with increased demand for farming land.

\subsection{Implications for Climate Mitigation}

Related to the strong human-spiritual bond that underpins the conservation of forests in Mbire is the communities' collective understanding of climate change and their thoughts about how to deal with it. Participants' construct of climate change was that "climate change is caused by the failure to strictly adhere to traditional practices that maintain the forests". They reported that, when people fail to adhere to local customs or violate local taboos, which they believe have helped in keeping the forests, the ancestors get upset. If the ancestors are unhappy, they are believed to give climatic signals; for example, in the form of drought or dry spells. The ancestors can also unleash problem animals such as elephants and lions that damage crops or attack people's livestock. They therefore interpret the change in the local climate system as a message requiring them to reflect on their practices, which they solidly relate to forest disturbances. The following comment illustrates their thinking:

The environmental changes that we are witnessing are a result of trivialization of our local customs especially by the new immigrants and young people. We can confidently connect the irregular rainfall patterns that we have witnessed since the 1990s with the influx of people from other places, including the desire to grow cotton. These developments have led to expansion of crop fields, encroaching into some forests. Because of this, the forests no longer build significant rainy clouds as they used to do. However, if you go to places such as Chidodo, where forests have not been disturbed, you will find that they are still getting a good harvest from normal rainfall.

(FGD, Gonono) 
Critical is their understanding of the relationship between forests and the local climate regime, including their climate-dependent livelihoods from which they have learnt ways of adapting to climate change. From their many years of interacting with the forests, the communities have learnt that their local climate system is influenced by the state of the forests. If the forests are degraded, then the climate system will be disturbed, leading to threats to their lives and livelihoods. This construct is similar to traditional science; hence, this validates IK and calls for it to be better recognized. The resultant displeasure of the ancestors, whom they view as critical in influencing weather and climate, is very worrying to the communities. Accordingly, the communities are challenged to engage in responsible behavior and take action towards responsible environmental practices. This is an opportunity to work with the indigenous communities towards designing climate mitigation programs, as reported by Chanza and de Wit [9], who highlighted the feasibility of adopting REDD+ and ecosystem-based adaptation $(\mathrm{EbA})$ in indigenous forestrich communities. For instance, in order for the ongoing REDD+ project to be effective, it can draw from the indigenous people's longstanding ways of conserving forests in the area. Perhaps this explains why externally funded projects fail to be sustainable in local communities: they fail to take cognizance of local people's perceptions. For example, as part of Ethiopia's Green Legacy Program, Ethiopia plans to plant 20 billion trees. Nevertheless, environmentalists are concerned as some of the trees are said to be detrimental to local ecosystems because they are not suited to local conditions [46].

Table 1 illustrates possibilities of integration between stakeholders involved in forestrelated management practices and indigenous communities in Mbire. This framework outlines the statutory mandate of institutions responsible for environmental management in Zimbabwe, including forestry resources, and how forestry-related projects could be strengthened by involving indigenous people with support from civil society. In all the institutions and projects specified, there are opportunities for the integration of indigenous people, who could use their knowledge and practices to promote sustainable forests once their roles are clearly defined. However, for the proposed engagement framework to work, the traditional institutions would need to be empowered so that their role could be given similar recognition as formal government institutions. The government would also need to harmonize the activities of the separate agencies to eliminate the overlaps and competing interests that are highlighted by Musakwa et al. [47].

Table 1. Stakeholder linkages with indigenous people for sustainable forest management in Mbire.

\begin{tabular}{ccc}
\hline Institution/Program & Role & $\begin{array}{c}\text { Institution-Indigenous People } \\
\text { Linkages }\end{array}$ \\
\hline Forestry Commission & $\begin{array}{c}\text { Forest management and regulation of } \\
\text { forestry resources use through issuance } \\
\text { of permits }\end{array}$ & $\begin{array}{c}\text { Engagement of communities in fireguard } \\
\text { construction and support from local } \\
\text { people in preventing unsanctioned forest } \\
\text { product extraction }\end{array}$ \\
\hline $\begin{array}{c}\text { Zimbabwe Parks and Wildlife } \\
\text { Management Authority }\end{array}$ & Wildlife management & $\begin{array}{c}\text { Engagement with communities to restrict } \\
\text { wildlife poaching }\end{array}$ \\
\hline $\begin{array}{c}\text { Environmental Management Agency } \\
\text { (EMA) }\end{array}$ & $\begin{array}{c}\text { Education and training on natural } \\
\text { resources use and environmental } \\
\text { management }\end{array}$ & $\begin{array}{c}\text { Traditional leaders' support in awareness } \\
\text { raising and training on sustainable } \\
\text { environmental management involving } \\
\text { local communities }\end{array}$ \\
\hline Mbire RDC & $\begin{array}{c}\text { Development of bylaws and projects for } \\
\text { the management of the environment } \\
\text { within its jurisdiction }\end{array}$ & $\begin{array}{c}\text { Enforcement of forest management } \\
\text { bylaws through the support of traditional } \\
\text { leaders and local communities' } \\
\text { participation in forest-related projects } \\
\text { such as CAMPFIRE and REDD+ }\end{array}$ \\
\hline
\end{tabular}


Table 1. Cont.

\begin{tabular}{|c|c|c|}
\hline Institution/Program & Role & $\begin{array}{l}\text { Institution-Indigenous People } \\
\text { Linkages }\end{array}$ \\
\hline CAMPFIRE & $\begin{array}{l}\text { Community-based wildlife management } \\
\text { initiatives }\end{array}$ & $\begin{array}{l}\text { Meaningful participation with clearly } \\
\text { defined governance involving indigenous } \\
\text { people in decision making and sharing of } \\
\text { wildlife proceeds }\end{array}$ \\
\hline Kariba REDD+ & $\begin{array}{l}\text { Emission reduction project through forest } \\
\text { management involving communities }\end{array}$ & $\begin{array}{l}\text { Clearly defined governance system } \\
\text { involving indigenous people in decision } \\
\text { making and sharing of project benefits }\end{array}$ \\
\hline $\begin{array}{l}\text { Non-Governmental Organizations } \\
\text { (NGOs) }\end{array}$ & $\begin{array}{l}\text { Advocacy on indigenous people's rights, } \\
\text { awareness raising and training on } \\
\text { sustainable resource use }\end{array}$ & $\begin{array}{l}\text { Strengthening indigenous-based } \\
\text { structures for articulating people's rights } \\
\text { with regard to resource use }\end{array}$ \\
\hline
\end{tabular}

What emerges from this discussion is that there are three key drivers likely to influence sustainable climate mitigation interventions in indigenous settings, which are as follows:

- Indigenous communities' acknowledgement of climate change;

- Their understanding that their behavior determines the state of the forests, which they understand to be critical in the local climate;

- Their perceptions on forestry resources which give them a collective obligation to jealously guard against misuse or abuse.

Notwithstanding the potential for forest assimilation of carbon in these communities, the size of the GHG reduction contribution cannot be easily calculated owing to the variable nature of indigenous practices. However, investigation of the IK on preserving forests can be a promising initiative for starting payment for ecosystem services, such as carbon credits to promote the sustainability of the projects in indigenous communities. In addition, the localized nature of IK practices, as reported by Cochran et al. [2] and Ford et al. [7], may make it difficult to institute large-scale IK-based forest management across other places where this knowledge form may not be prevalent. This means that mitigation projects involving indigenous people are likely to be isolated and confined to those areas where IK is still prevalent. Consequently, this problem may limit private-sector-based financing to support mitigation. However, non-profit-oriented organizations can work with such communities and realize mitigation benefits, which can also extend to other places outside project areas. These projects are likely to have a cumulative carbon assimilation effect which can enhance the fight against climate change. Espousing this thinking, we argue that the spatial limitations of IK utility in mitigation science could be misleading and that there is a need to work with indigenous communities in mitigation interventions.

\section{Conclusions}

The participatory engagement with local villagers selected on the basis of their profound knowledge about their local environment gave useful pointers about the motivation behind forestry resources management in indigenous settings. These insights gave indicators about the prospects of working with indigenous communities to implement mitigation projects. The participants were motivated to share their knowledge and practices in an activity in which they proudly communicated about the human-nature relationships and the aspect of spirituality that maintain their existence. With reference to climate regulation, it appears that the spatial confinement of IK utility, as it is currently understood, has marginalized the critical role that indigenous people can play in forest management. The climate science community needs to turn its attention to the mitigation potentials that emerge from carefully managed forests in isolated pockets of indigenous communities and work with them in designing GHG stabilization measures. The success of mitigation gains from forest conservation in indigenous settings is largely influenced by the strong perceptions of closeness to the trees that the communities have. However, the main threats 
to this relationship seem to be coming from mistrust between the locals and the exogenous conservation bodies, whose conservation approaches end up alienating and trivializing the belief systems of the local people. Despite the constraints on the scale at which indigenousbased GHG sequestration in local forests can contribute, we believe that the escalating threat of climate change demands that collective efforts be put in place if communities are to be protected from the risks of a changing climate. The climate change research community can learn much from working with indigenous communities and understanding their long-term ways of forest management and the mitigation contributions that such forests can provide.

Supplementary Materials: The following are available online at https:/ /www.mdpi.com/article/10 .3390/su13115885/s1.

Author Contributions: N.C. conceptualized the study, collected and analyzed data and prepared the draft manuscript. W.M. produced the study area map, reviewed and edited the draft manuscript and was responsible for funding acquisition. All authors have read and agreed to the published version of the manuscript.

Funding: This research was funded by the German Academic Exchange Service (DAAD) under climapAfrica Research for postdocs and alumni and the Faculty of Engineering and the Built Environment of the University of Johannesburg.

Institutional Review Board Statement: The study was conducted according to the guidelines of the Declaration of Helsinki, and approved by the Ethics and Plagiarism Committee of the University of Johannesburg (Ethical Clearance Number UJ_FEBE_FEPC_00046 on 6 June 2020).

Informed Consent Statement: Informed consent was obtained from all subjects involved in the study.

Data Availability Statement: The data that support the findings of this study may be available on request from the corresponding author, N.C. These data are not publicly available because of agreements made with the participants, who are the custodians of their indigenous knowledge as determined by both research agreements with the indigenous communities as well as university ethics committee.

Acknowledgments: We are grateful to the participants from Mbire District, who willingly and generously shared their knowledge about their local forests and spent their much valued time with us. In particular, we are indebted to the support given by the councilors who helped us identify the desired villages. We also acknowledge the invaluable support given by the village heads from each of the targeted villages, who assisted in identifying the most appropriate participants and helped in organizing focus group discussions. The work of local research assistants in field navigation and transcribing and translating field notes is also much valued.

Conflicts of Interest: The authors declare no conflict of interest. The funders had no role in the design of the study; in the collection, analyses, or interpretation of data; in the writing of the manuscript, or in the decision to publish the results.

\section{References}

1. Boillat, S.; Berkes, F. Perception and interpretation of climate change among Quechua farmers of Bolivia: Indigenous knowledge as a resource for adaptive capacity. Ecol. Soc. 2013, 18, 21. [CrossRef]

2. Cochran, P.; Huntington, O.H.; Pungowiyi, C.; Tom, S.; Chapin, F.S., III; Huntington, H.P.; Maynard, N.G.; Trainor, S.F. Indigenous frameworks for observing and responding to climate change in Alaska. Clim. Chang. 2013, 120, 557-567. [CrossRef]

3. Klein, J.A.; Hopping, K.A.; Yeh, E.T.; Nyima, Y.; Boone, R.B.; Galvin, K.A. Unexpected climate impacts on the Tibetan Plateau: Local and scientific knowledge in findings of delayed summer. Glob. Environ. Chang. 2014, 28, 141-152. [CrossRef]

4. Intergovernmental Panel on Climate Change (IPCC). Global Warming of $1.5^{\circ} \mathrm{C}$. An IPCC Special Report on the Impacts of Global Warming of $1.5^{\circ} \mathrm{C}$ Above Pre-Industrial Levels and Related Global Greenhouse Gas Emission Pathways, in the Context of Strengthening the Global Response to the Threat of Climate Change, Sustainable Development, and Efforts to Eradicate Poverty; Masson-Delmotte, V., Zhai, P., Pörtner, H.O., Roberts, D., Skea, J., Shukla, P.R., Pirani, A., Moufouma-Okia, W., Péan, C., Pidcock, R., et al., Eds.; 2018; Available online: https://www.ipcc.ch/site/assets/uploads/sites/2/2019/06/SR15_Full_Report_Low_Res.pdf (accessed on 10 March 2021). 
5. Moss, R.H.; Avery, S.; Baja, K.; Burkett, M.; Chischilly, A.M.; Dell, J.; Fleming, P.A.; Geil, K.; Jacobs, K.; Jones, A.; et al. Evaluating knowledge to support climate action: A framework for sustained assessment. Weat. Clim. Soc. 2019, 11, 465-487. [CrossRef]

6. Parsons, M.; Fisher, K.; Nalau, J. Alternative approaches to co-design: Insights from indigenous/academic research collaborations. Curr. Opin. Environ. Sustain. 2016, 20, 99-105. [CrossRef]

7. Ford, J.D.; Vanderbilt, W.; Berrang-Ford, L. Authorship in IPCC AR5 and its implications for content: Climate change and Indigenous populations in WGII. Clim. Chang. 2012, 113, 201-213. [CrossRef] [PubMed]

8. Reyes-García, V.; Fernández-Llamazares, A.; García-del-Amo, D.; Cabeza, M. Operationalizing local ecological knowledge in climate change research: Challenges and opportunities of citizen science. In Changing Climate, Changing Worlds. Local Knowledge and the Challenges of Social and Ecological Change; Welch-Devine, M., Sourdril, A., Burke, B.J., Eds.; Springer: Berlin, Germany, 2020; pp. 183-197. [CrossRef]

9. Chanza, N.; de Wit, A. Rediscovering Indigenous Climate Knowledge for better Responses to Climate Change: Insights from Muzarabani. Int. J. Clim. Chang. Impacts Responses 2015, 6, 19-35. [CrossRef]

10. Balvanera, P.; Calderón-Contreras, R.; Castro, A.J.; Felipe-Lucia, M.R.; Geijzendorffer, I.R.; Jacobs, S.; Martín-López, B.; Arbieu, U.; Speranza, C.I.; Locatelli, B.; et al. Interconnected place-based social-ecological research can inform global sustainability. Curr. Opin. Environ. Sustain. 2017, 29, 1-7. [CrossRef]

11. Fernandez-Llamazares, Á.; Garcia, R.; Díaz-Reviriego, A.I.; Cabeza, M.; Pyhälä, A.; Reyes-Garcia, V. An empirically tested overlap between indigenous and scientific knowledge of a changing climate in Bolivian Amazonia. Reg. Environ. Chang. 2017, 17, 1673-1685. [CrossRef]

12. Dervieux, Z.; Belgherbi, M. "We Used to go Asking for the Rains": Local Interpretations of Environmental Changes and Implications for Natural Resource Management in Hwange District, Zimbabwe, 35-54. In Changing Climate, Changing Worlds. Local Knowledge and the Challenges of Social and Ecological Change; Welch-Devine, M., Sourdril, A., Burke, B.J., Eds.; Springer: Berlin, Germany, 2020; pp. 35-54. [CrossRef]

13. García-del-Amo, D.; Mortyn, P.G.; Reyes-García, V. Including indigenous and local knowledge in climate research: An assessment of the opinion of Spanish climate change researchers. Clim. Chang. 2020, 160, 67-88. [CrossRef]

14. Weber, A.; Schmidt, M. Local perceptions, knowledge systems and communication problems around the climate change discourse-Examples from the Peruvian Andes. Erdkunde 2016, 70, 355-366. [CrossRef]

15. Chemhuru, M.; Masaka, D. Taboos as sources of Shona people's environmental ethics. J. Sustain. Dev. Afr. 2020, 12, 121-133.

16. United Nations (UN) (online). Sustainable Development Goals. Available online: https://sdgs.un.org/goals (accessed on 16 April 2021).

17. Reyes-García, V.; Fernández-Llamazares, A.; Guèze, M.; Garcés, A.; Mallo, M.; Vila-Gómez, M.; Vilaseca, M. Local indicators of climate change: The potential contribution of local knowledge to climate research. Clim. Chang. 2016, 7, 109-124. [CrossRef]

18. Orlove, B.; Roncoli, C.; Kabugo, M.; Majugu, A. Indigenous climate knowledge in southern Uganda: The multiple components of a dynamic regional system. Clim. Chang. 2010, 100, 243-265. [CrossRef]

19. Panda, A. Exploring climate change perceptions, rainfall trends and perceived barriers to adaptation in a drought affected region in India. Nat. Hazards 2016, 84, 777-796. [CrossRef]

20. Marin, A. Riders under storms: Contributions of nomadic herders' observations to analysing climate change in Mongolia. Glob. Env. Chang. 2010, 20, 162-176. [CrossRef]

21. Sanchez, A.C.; Fandohan, B.; Assogbadjo, A.E.; Sinsin, B. A countrywide multi-ethnic assessment of local communities' perception of climate change in Benin (West Africa). Clim. Dev. 2012, 4, 114-128. [CrossRef]

22. Crona, B.; Wutich, A.; Slade, A.; Gartin, M. Perceptions of climate change: Linking local and global perceptions through a cultural knowledge approach. Clim Chang. 2013, 119, 519-531. [CrossRef]

23. Da Silva, C.J.; Albernaz-Silveira, R.; Nogueira, P.S. Perceptions on climate change of the traditional community Cuiabá Mirim, Pantanal Wetland, Mato Grosso, Brazil. Clim. Chang. 2014, 127, 83-92. [CrossRef]

24. Savo, V.; Lepofsky, D.; Benner, J.P.; Kohfeld, K.E.; Bailey, J.; Lertzman, K. Observations of climate change among subsistenceoriented communities around the world. Nat. Clim. Chang. 2016, 6, 462-473. [CrossRef]

25. Makondo, C.C.; Thomas, D.S.G. Climate change adaptation: Linking indigenous knowledge with western science for effective adaptation. Environ. Sci. Policy 2018, 88, 83-91. [CrossRef]

26. Codjoe, S.N.A.; Owusu, G.; Burkett, V. Perception, experience, and indigenous knowledge of climate change and variability: The case of Accra, a sub-Saharan African city. Reg. Environ. Chang. 2014, 14, 369-383. [CrossRef]

27. Kolawole, O.D.; Motsholapheko, M.R.; Ngwenya, B.N.; Thakadu, O.; Mmopelwa, G.; Kgathi, D.L. Climate Variability and Rural Livelihoods: How Households Perceive and Adapt to Climatic Shocks in the Okavango Delta, Botswana. Weather Clim. Soc. 2016, 8, 131-145. [CrossRef]

28. Musarandega, H.; Chingombe, W.; Pillay, R. Harnessing local traditional authorities as a potential strategy to combat the vagaries of climate change in Zimbabwe. Jàmbá J. Dis. Risk Stud. 2018, 10, a651. [CrossRef]

29. Eitzel, M.V.; Solera, J.; Wilson, K.B.; Neves, K.; Fisher, A.C.; Veski, A.; Omoju, O.E.; Mawere Ndlovu, A.; Mhike Hove, E. Indigenous climate adaptation sovereignty in a Zimbabwean agro-pastoral system: Exploring definitions of sustainability success using a participatory agent-based model. Ecol. Soc. 2020, 25, 13. [CrossRef] 
30. Whitney, C.K.; Frid, A.; Edgar, B.K.; Walkus, J.; Siwallace, P.; Siwallace, I.L.; Ban, N.C. "Like the plains people losing the buffalo": Perceptions of climate change impacts, fisheries management, and adaptation actions by Indigenous peoples in coastal British Columbia, Canada. Ecol. Soc. 2020, 25, 33. [CrossRef]

31. Nyong, A.; Adesina, F.; Elasha, B.O. The value of indigenous knowledge in climate change mitigation and adaptation strategies in the African Sahel. Mit. Adap. Strat. Glob. Chang. 2007, 12, 787-797. [CrossRef]

32. Boko, M.; Niang, I.; Nyong, A.; Vogel, C.; Githeko, A.; Medany, M.; Osman-Elasha, B.; Tabo, R.; Yanda, P. Africa. In Climate Change 2007: Impacts, Adaptation and Vulnerability. Contribution of Working Group II to the Fourth Assessment Report of the Intergovernmental Panel on Climate Change; Parry, M.L., Canziani, O.F., Palutikof, J.P., van der Linden, P.J., Hanson, C.E., Eds.; Cambridge University Press: Cambridge, UK, 2007; pp. 433-467.

33. Tol, R.S.J. Adaptation and mitigation: Trade-offs in substance and methods. Environ. Sci. Policy 2005, 8, 572-578. [CrossRef]

34. Adger, W.N.; Arnell, N.W.; Tompkins, E.L. Successful adaptation to climate change across scales. Glob. Environ. Chang. 2005, 15, 77-86. [CrossRef]

35. Chishakwe, N.; Murray, L.; Chambwera, M. Building Climate Change Adaptation on Community Experiences: Lessons from CommunityBased Natural Resource Management in Southern Africa; International Institute for Environment and Development: London, UK, 2012.

36. Wilbanks, T.J.; Sathaye, J. Integrating mitigation and adaptation as responses to climate change: A synthesis. Mit. Adapt. Strat. Glob. Chang. 2007, 12, 957-962. [CrossRef]

37. Gumindoga, W.; Murwira, A.; Rwasoka, D.T.; Jahure, F.B.; Chikwiramakomo, L. The spatio-temporal soil moisture variation along the major tributaries of Zambezi River in the Mbire District, Zimbabwe. J. Hydrol. Reg. Stud. 2020, 32, 100753. [CrossRef]

38. Manatsa, D.; Mushore, T.D.; Gwitira, I.; Wuta, M.; Chemura, A.; Shekede, M.D.; Mugandani, R.; Sakala, L.C.; Ali, L.H.; Masukwedza, G.I.; et al. Revision of Zimbabwe's Agro-Ecological Zones; A Technical Report submitted to the Zimbabwe National Geospatial and Space Agency (ZINGSA) for the Ministry of High-er and Tertiary Education; Innovation, Science and Technology Development: Harare, Zimbabwe, 2020. in press.

39. Bola, G.; Mabiza, C.; Goldin, J.; Kujinga, K.; Nhapi, I.; Makurira, H.; Mashauri, D. Coping with droughts and floods: A Case study of Kanyemba, Mbire District, Zimbabwe. Phys. Chem. Earth 2014, 67-69, 180-186. [CrossRef]

40. Mavhura, E. Systems analysis of vulnerability to hydrometeorological threats: An exploratory study of vulnerability drivers in northern Zimbabwe. Int. J. Dis. Risk Sci. 2019, 10, 204-219. [CrossRef]

41. Baudron, F.; Corbeels, M.; Monicat, F.; Giller, K.E. Cotton expansion and biodiversity loss in African savannahs, opportunities and challenges for conservation agriculture: A review paper based on two case studies. Biodivers. Conserv. 2009, 18, 2625-2644. [CrossRef]

42. Byers, B. Mhondoro: Spirit Lions and Sacred Forests. In This Sacred Earth: Religion, Nature, Environment, 2nd ed.; Gottlieb, S., Ed.; Routledge: New York, NY, USA, 2004.

43. Jani, V.; de Wit, A.H.; Webb, N.L. An assessment of human-wildlife conflicts in local communities bordering Chewore and Dande Safari areas in Mbire District, northern Zimbabwe. Afr. J. Ecol. 2020, 58, 891-986. [CrossRef]

44. Government of Zimbabwe (GoZ). Background Report on National Policy Priorities, Initiatives and Institutions Relevant for Climate Change Capacity Development in Zimbabwe; Ministry of Environment, Climate, Tourism and Hospitality Industry: Harare, Zimbabwe, 2020.

45. Creswell, J.W. Qualitative Enquiry and Research Design: Choosing Among Five Approaches, 3rd ed.; SAGE Publications: Thousand Oaks, CA, USA, 2013.

46. Magaju, C.; Ann Winowiecki, L.; Crossland, M.; Frija, A.; Ouerghemmi, H.; Hagazi, N.; Sinclair, F. Assessing context-specific factors to increase tree survival for scaling ecosystem restoration efforts in East Africa. Land 2020, 9, 494. Available online: https: / / www.mdpi.com/2073-445X/9/12/494 (accessed on 25 March 2021).

47. Musakwa, W.; Gumbo, T.; Paradza, G.; Mpofu, E.; Nyathi, N.A.; Selamolela, N.B. Partnerships and stakeholder participation in the management of national parks: Experiences of the Gonarezhou National Park in Zimbabwe. Land 2020, 9, 399. [CrossRef] 